\title{
Kloning dan Sekuensing Gen Xilanase dengan Produk Gen Berukuran 30 kDa dari Bacillus halodurans CM1 pada Escherichia coli DH5 $\alpha$
}

\author{
Dearesty Safirah ${ }^{1}$, Is Helianti ${ }^{2}$, Hermin Pancasakti Kusumaningrum ${ }^{1}$ dan Anto Budiharjo ${ }^{1}$ \\ ${ }^{1}$ Departemen Biologi, Fakultas Sains dan Matematika, Universitas Diponegoro \\ Jalan Prof. H. Soedarto, SH, Tembalang, Semarang 50275. \\ ${ }^{2}$ Pusat Teknologi Bioindustri, Badan Pengkajian dan Penerapan Bioteknologi, Gedung 611, LAPTIAB-BPPT, \\ PUSPIPTEK, Serpong, Tangerang Selatan. \\ *Penulis korespondensi; Email: is.helianti@bppt.go.id
}

\begin{abstract}
The paper industry contributed the environment pollution due to chlor substances. Utilization of alkalothermophilic xylanase enzyme as a biocatalyst in the production of paper may become an environmentally friendly biobleaching alternative. Bacillus halodurans CM1 produces xilanase enzyme that had optimal activity at $\mathrm{pH} 9$ and temperature $70^{\circ} \mathrm{C}$. Previous study showed that this CM1 strains has several xilanase genes. The cloning of one of these alkalothermophiic xylanase (alkxyn) gene has been already conducted. This study aimed to clone alkxyn gene that encode alkalothermophilic xylanase enzyme from B. halodurans CM1 into Escherichia coli DH5 $\alpha$. Amplification of alkxyn has been carried out using primers for amplification xylanase $30 \mathrm{kDa}$. The alkxyn gene fragment was inserted into pGEM-T Easy vector and then transformed into E. coli DH5 $\alpha$. The results showed that the recombinant of $E$. coli DH5 $\alpha$ harboring alkxyn gene from $B$. halodurans CM1 has been obtained. The sequences analysist based on BLAST showed that alkxyn fragment has homology (99\%) with the alkaliphilic xylanase gene from Bacillus sp. 31 which encodes alkaliphilic xilanase (Genebank assession number: JF912895.1).
\end{abstract}

Keywords: cloning, Bacillus halodurans CM1, xylanase, alkalothermophilic.

\begin{abstract}
Abstrak
Industri kertas menyumbang tingkat pencemaran lingkungan yang tinggi karena menggunakan zat kimia berbahaya, khususnya klorin. Pemanfaatan enzim xilanase alkalotermofilik sebagai biokatalis dalam produksi kertas dapat menjadi alternatif yang ramah lingkungan dengan teknologi biobleaching. Bacillus halodurans CM1 menghasilkan enzim xilanase yang mempunyai aktivitas optimum pada $\mathrm{pH} 9$ dan suhu $70^{\circ} \mathrm{C}$. Penelitian terdahulu menunjukkan bahwa galur bakteri CM1 kemungkinan memiliki lebih dari satu gen xilanase alkalotermofilik (alkxyn). Salah satu gen xilanase telah dikloning dan diekspresikan pada penelitian sebelumnya. Penelitian ini bertujuan untuk mengkloning gen alkxyn lainnya yang menyandi enzim xilanase alkalotermofilik dari $B$. halodurans CM1 ke Escherichia coli DH5 $\alpha$. Amplifikasi gen alkxyn dilakukan dengan metode Polymerase Chain Reaction (PCR) menggunakan primer yang telah didesain untuk mengamplifikasi gen alkxyn. Produk amplifikasi berukuran $30 \mathrm{kDA}$ yang selanjutnya disisipkan pada vektor pGEM-T Easy dan ditransformasikan ke dalam bakteri kompeten E. coli DH5 $\alpha$. Hasil penelitian menunjukkan bahwa rekombinan berupa fragmen gen alkxyn yang berukuran $960 \mathrm{bp}$ dari B. halodurans CM1 yang disisipkan ke dalam plasmid pGEM-T Easy telah diperoleh. Hasil penyejajaran sekuens melalui BLAST menunjukkan bahwa fragmen alkxyn memiliki tingkat homologi (99\%) dengan gen alkaliphilic xylanase pada spesies Bacillus sp. 31 yang menyandi enzim xilanase alkalofilik. (No akses GenBank: JF912895.1).
\end{abstract}

Kata kunci: Kloning, Bacillus halodurans CM1, xilanase, alkalotermofilik

\section{PENDAHULUAN}

Industri kertas merupakan salah satu industri yang memegang peranan penting bagi perekonomian Indonesia, karena Indonesia termasuk produsen kertas terbesar di Asia. Industri kertas Indonesia yang begitu pesat di sisi lain 
mengakibatkan terjadinya pencemaran lingkungan, hal ini dikarenakan kegiatan utama dalam industri kertas adalah proses pembuatan bubur kertas (pulping) yang menggunakan bahan-bahan kimia seperti klorin pada tahap bleaching (pemutihan) yang diketahui kurang ramah lingkungan karena menghasilkan limbah berbahaya yang bersifat karsinogenik (Fuadi dan Sulistya, 2008). Alternatif pengganti bahan kimia yang relatif lebih ramah lingkungan yaitu dengan penggunaan enzim untuk proses bleaching

Enzim yang paling umum digunakan dalam proses biobleaching adalah xilanase. Enzim xilanase diketahui mampu menjadi fasilitator dalam memurnikan komponen selulosa karena merupakan enzim yang dapat menghidrolisis hemiselulosa dan lignin. Ulfah et al., (2011) telah berhasil mengisolasi mikroba penghasil enzim xilanase alkalotermofilik Bacillus halodurans CM1 dari Sumber Air Panas Cimanggu yang diketahui mampu memproduksi xilanase dengan aktivitas optimum pada pH 9 dan suhu $70^{\circ} \mathrm{C}$. Industri kertas memerlukan xilanase yang mampu bekerja secara optimal dalam suhu tinggi dan kondisi pH alkali yang merupakan kondisi perlakuan yang diperlukan pada proses pulping. Penelitian sebelumnya menunjukkan bahwa $B$. halodurans CM1 mempunyai beberapa gen xilanase (Helianti et al., 2014).

Upaya perbanyakan enzim xilanase dapat dilakukan dengan teknologi DNA rekombinan yang lebih efisien yaitu dengan mengkloning gen penyandi enzim xilanase alkalotermofilik pada Escherichia coli DH5 $\alpha$ sehingga terdapat mikroorganisme rekombinan yang dapat mengekspresikan gen tersebut dan produktivitas enzim target akan meningkat. Noer (2011), telah berhasil mengisolasi gen xilanase alkaltermofilik yang produk gennya berukuran $45 \mathrm{kDa}$. Oleh karena itu, penelitian ini bertujuan untuk mengkloning gen alkxyn lainnya yang menyandi enzim xilanase alkalotermofilik dari B. halodurans CM1 ke E. coli DH5 $\alpha$. Amplifikasi gen alkxyn dilakukan dengan metode Polymerase Chain Reaction (PCR) menggunakan primer yang telah didesain untuk mengamplifikasi gen alkxyn yang produk gennya berukuran $30 \mathrm{kDa}$.

\section{BAHAN DAN METODE Waktu dan Tempat Penelitian}

Sumber gen menggunakan Bacillus halodurans CM1 (Ulfah et al, 2011) koleksi Laboraturium Teknologi Bioindustri, Pusat Teknologi Bioindustri, Badan Pengkajian dan Penerapan Bioteknologi (BPPT). Sel inang (host) dan vektor untuk kloning menggunakan Escherichia coli DH5 $\alpha$ dan plasmid pGEM-T Easy.

\section{Amplifikasi Fragmen Gen alkxyn Menggunakan Polymerase Chain Reaction (PCR)}

B. halodurans CM1 dikultur menggunakan medium horikoshi pada $\mathrm{pH} 9$ dan suhu $55^{\circ} \mathrm{C}$ sesuai yang dilaporkan Ulfah et al., (2011). Isolasi DNA genom $B$. halodurans CM1 menggunakan metode ekstraksi fenol-kloroform seperti yang telah dilakukan sebelumnya (Ulfah et al., 2011; Noer, 2011). Karakterisasi DNA genom dilakukan dengan elektroforesis gel agarose $1 \%$. Kemurnian DNA dihitung menggunakan nanodrop. Amplifikasi gen alkxyn dari B. halodurans CM1 menggunakan KAPA Taq Hot Start DNA Polymerase (KAPA biosystem) dengan pasangan primer F-alkxyn-det dan R-alkxyn30-stop. Susunan basa nukleotida untuk primer forward (Falkxyn-det) adalah 5' ATGGAGAGTCGGACAGAAACTAATCGTGC3', sedangkan susunan nukleotida primer reverse (R-alkxyn30-stop) adalah 5'TTAATAGGTGCCGAAATGGATAGG-3' .

Primer didesain berdasarkan studi bioinformatika gen xilanase yang terdapat di GenBank dan data penelitian sebelumnya (Helianti et al., 2014). Program PCR terdiri dari denaturasi awal pada suhu $95^{\circ} \mathrm{C}$ selama 3 menit dan 30 siklus reaksi yang terdiri dari denaturasi pada suhu $95^{\circ} \mathrm{C}$ selama 30 detik, penempelan primer pada suhu $59^{\circ} \mathrm{C}$ selama 30 detik. Akhir pemanjangan dilakukan pada tahap akhir proses PCR dengan waktu 10 menit pada suhu $72^{\circ} \mathrm{C}$. Karakterisasi DNA dilakukan menggunakan gel agarosa dengan konsentrasi gel $1 \%$. Molekul DNA dipurifikasi menggunakan Gel/PCR DNA Extraction Kit (Geneaid) untuk kloning.

\section{Kloning Gen alkxyn}

Prosedur kloning dan verifikasi hasil kloning berdasarkan protokol Sambrook (2001). Kloning 
gen alkxyn diawali dengan proses ligasi pada plasmid vektor, transformasi pada E. coli DH5 $\alpha$ dan seleksi rekombinan pembawa plasmid dengan DNA sisipan. Ligasi fragmen gen alkxyn ke dalam vektor pGEM-T Easy dilakukan menggunakan enzim T4 DNA ligase dengan rasio molar 3:1. Inkubasi dilakukan pada suhu $4^{\circ} \mathrm{C}$ dalam waktu semalam. Hasil ligasi ditransformasi pada bakteri kompeten E. coli DH5 $\alpha$. Transformasi menggunakan teknik kejut panas (Heat shock) yang dimodifikasi yaitu dengan perubahan suhu secara mendadak dari inkubasi es ke termomixer $\left(42^{\circ} \mathrm{C}\right)$ selama 1 menit dan diinkubasi kembali dalam es selama 2 menit. Bakteri kompeten $E$. coli DH5 $\alpha$ yang telah di transformasi dikultur dalam medium SOC (Tripton 20g, Yeast Ekstrak 5g, $\mathrm{NaCl} 0,585 \mathrm{~g}, \mathrm{KCl} 0,186 \mathrm{~g}$, glukosa 2M) dan diinkubasikan selama 1 jam pada suhu $37^{\circ} \mathrm{C}$ dengan kecepatan $150 \mathrm{rpm}$. Seleksi koloni dilakukan dengan menumbuhkan bakteri transforman pada media yang mengandung antibiotik ampisilin dan IPTG X-gal. Koloni berwarna putih yang tumbuh merupakan koloni yang diduga mengandung plasmid rekombinan.

\section{Verifikasi Hasil Kloning}

Verifikasi digesti menggunakan dua enzim restriksi yaitu EcoRI dilakukan pada transforman kandidat plasmid rekombinan hasil kloning yang telah diisolasi dengan metode alkali. Inkubasi dilakukan pada suhu $37^{\circ} \mathrm{C}$ selama 2 jam. Hasil digesti dianalisis dengan elektroforesis gel agarosa $1 \%$.

\section{HASIL DAN PEMBAHASAN}

\section{Amplifikasi Gen alkxyn}

Gen alkxyn yang menyandi xilanase alkalotermofilik diprediksi berukuran 960 bp berdasarkan data yang berada pada GenBank (http://www.ncbi.nlm.nih.gov). Hasil ekstraksi genom menunjukkan pita DNA yang tebal dan spesifik pada ukuran diatas 10.000 bp (Gambar 1), yang menunjukkan bahwa genom DNA telah terisolasi. Menurut Takami (2000) bahwa ukuran keseluruhan genom $B$. halodurans $\mathrm{C}-125$ adalah 4.202.353 bp. Konsentrasi DNA hasil ekstraksi sebesar $0,31 \mathrm{~g} / \mathrm{L}$

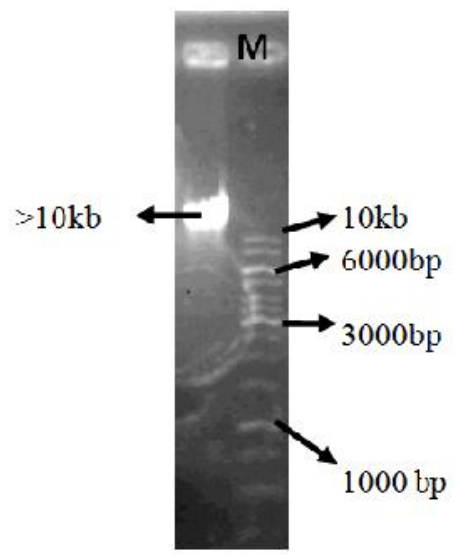

Gambar 1. Hasil ekstraksi DNA genom B. halodurans CM1. Lajur 1=hasil ekstraksi DNA genom ukuran >10kb. M= $1 \mathrm{~kb}$ DNA Ladder.

Produk PCR (Gambar 2) menunjukkan fragmen gen alkxyn dari B. halodurans CM1 berukuran \pm 960 bp yang berhasil diamplifikasi secara spesifik, tampak hanya satu pita DNA yang terbentuk dari hasil amplifikasi. Keberhasilan proses amplifikasi ditentukan oleh beberapa faktor seperti konsentrasi dan desain primer yang digunakan, deoksiribonukleotida triposfat (dNTPs), komposisi buffer, jumlah siklus reaksi, enzim taq polymerase dan kontaminasi yang terjadi saat peracikan komponen PCR (Yuwono, 2006). 


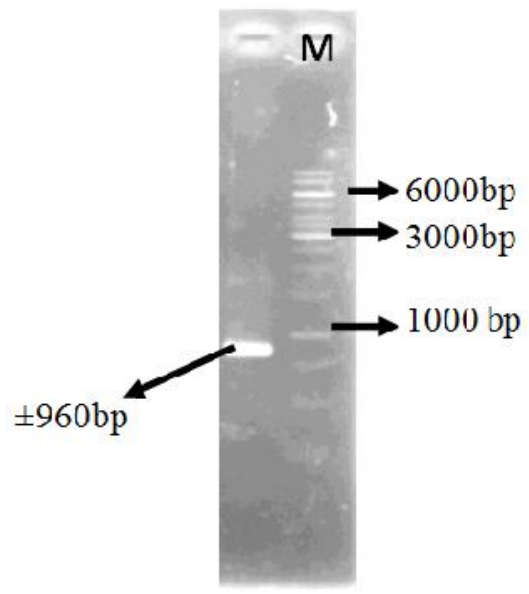

Gambar 2. Amplifikasi gen alkxyn. M=1kb DNA Ladder.

\section{Transformasi}

Keberhasilan transformasi ditandai dengan adanya ekspresi gen resistensi antibiotik yang dibawa plasmid pGEM-T Easy sehingga transforman dapat hidup pada medium yang mengandung antibiotik (medium seleksi) berupa ampisilin, selain itu juga terdapatnya koloni putih hasil screening white-blue colony. Gambar 3 memperlihatkan adanya koloni tumbuh berwarna putih dan biru. Menurut Quail (2005) Koloni putih yang diduga merupakan koloni rekombinan dimana terjadi supresi gen lacZ, sedangkan koloni biru diduga proses insersi gen pada plasmid tidak berhasil dikarenakan terjadi gen lacZ terekspresi. Masuk dan stabilnya plasmid dalam sel inang mengubah sifat dasar E. coli DH5 $\alpha$ yang semula sensitif terhadap antibiotik ampisilin (Amp-s) menjadi resisten terhadap ampisilin (Amp-r)

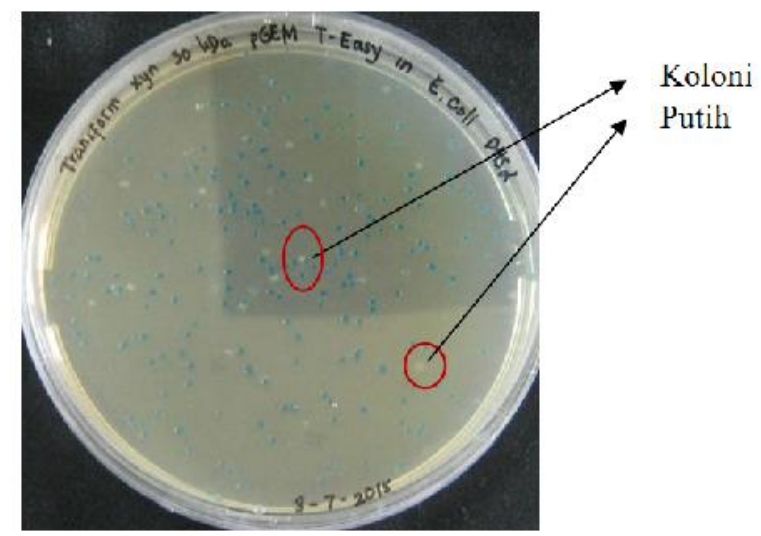

Gambar 3. Hasil Transformasi plasmid rekombinan ke dalam E. coli DH5 $\alpha$ 


\section{Verifikasi Hasil Kloning}

Hasil digesti plasmid rekombinan oleh enzim EcoRI menunjukkan posisi dua pita yang berbeda karena terjadi religasi pada plasmid dan insert DNA pada pemotongan EcoRI yaitu pada ukuran \pm 980 bp dan \pm 2997 bp, adapun saat karakterisasi plasmid rekombinan yang belum di digesti dengan elektroforesis gel agarose $1 \%$ hanya

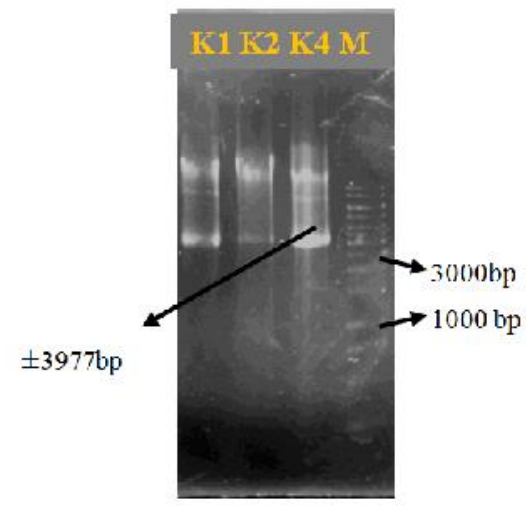

terdapat satu pita yaitu pada ukuran \pm 3975 bp. Perbedaan yang terlihat cukup signifikan mengindikasikan gen alkxyn telah tersisipkan pada plasmid pGEM-T Easy. Plasmid hasil ekstraksi tidak dapat ditentukan ukuran fragmennya secara tepat sebelum didigesti menjadi bentuk linier (Carson and Robertson, 2004

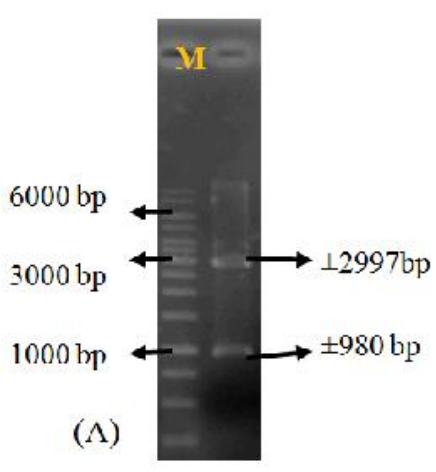

Gambar 4. (A) Hasil ekstraksi plasmid rekombinan dari E.coli DH5 $\alpha$. Lajur 1-3=hasil ekstraksi plasmid dari 3 klon berbeda (klon1, klon2, dan klon 4). M=1 kb DNA Ladder.

(B) Hasil digesti restriksi plasmid rekombinan dari E.coli DH5 $\alpha$ dengan enzim EcoRI. 


\section{KESIMPULAN}

Fragmen gen alkxyn yang berasal dari genom isolat $B$. halodurans CM1 telah berhasil diinsersikan ke dalam vektor plasmid pGEM-T Easy yang kemudian dikloning ke E. coli DH5 $\alpha$. Keberhasilan kloning telah dibuktikan dengan analisa restriksi menggunakan EcoRI yang menunjukkan pita berukuran \pm 980 bp dan \pm 2997 bp.

\section{UCAPAN TERIMAKASIH}

Penelitian ini dibiayai oleh dana penelitian DIPA-BPPT tahun 2015. Penulis berterimakasih pada Sri Aprianti, S.Pd dan Dr. Is Helianti, M.Sc atas arahan dan bantuan teknis yang telah diberikan selama pelaksanaan penelitian.

\section{DAFTAR PUSTAKA}

Carson, S. and D. Robertson. 2006. Manipulation and Expression of Recombinant DNA: A Laboratory Manual Second Edition. Elsevier Academic Press. London.

Fuadi, A. M. dan H. Sulistya. 2008. Pemutihan Pulp dengan Hidrogen Peroksida. Jurnal Reaktor. 2(12): 123-128.

Is Helianti*, Maria Ulfah, Budiasih Wahyuntari, Niknik Nurhayati, Edi Wahjono, and Dian Fajar. Vitia Ningrum. 2014. Properties of Native and Recombinant Thermoalkalophilic Xylanases from Bacillus halodurans CM1, and Application of the Enzymes in Industrial Deinking Process. The $I^{\text {st }}$ ASEAN Microbial Biotechnology Conference 2014 (AMBC2014). 19-21 Feb 2014. Bangkok, Thailand.

Noer, S. 2011. Kloning Gen Xilanase Alkalotermofilik pada Escherichia coli DH5 $\alpha$ dan Karakterisasi Produk Gennya. Tesis. Universitas Indonesia. Depok.

Quail, M. A. 2005. DNA Cloning. Encyclopedia Of Life Sciences. New York: John Willey and Sons Ltd. doi: 10.1038/npg.els.0005344.

Sambrook, J., dan D.W. Russel. 2001. Molecular Cloning a Laboratory Manual. Cold Spring Harbor, NY, USA: Cold Spring Harbor Laboratory Press.

Takami, H., K. Nakasone, Y. Takaki, G. Maeno, R. Sasaki, N. Masui, F. Fuji, C. Hirama, Y. Nakamura, N. Ogasawara, S. Kuhara, and K. Horikoshi. 2000. Complete Genome Sequence of The Alkaliphilic Bacterium Bacillus halodurans and Genomic Sequence Comparison With Bacillus subtilis. Nucleic Acid Research. 28(21):4317-4331. (Yuwono, 2006).

Ulfah, M., I. Helianti, B. Wahyuntari, and N. Hurhayati. 2011. Characterization of a New Thermoalkalophilic Xylanase Producing Bacterial Strain Isolated from Cimanggu Hot Spring, West Java, Indonesia. Microbiology Indonesia. 3(5): 139-143.

Yuwono, T. 2006. Teori dan Aplikasi Polymerase Chain Reaction. Erlangga. Jogjakarta. 
BIOMA, Desember 2016

ISSN: 1410-8801

Vol. 18, No. 2, Hal. 167-172 